\title{
Research Paper \\ Effectiveness of the Nurturing Program for Parents and their Children with Special Needs and their Health Challenges on the Perceived Energy for Parenting and Mindfulness
}

Vahid Hajialiani ${ }^{1}$, Afshin Tahmasbi ${ }^{2}$, Adeleh Shakhs Bolandghadr ${ }^{3}$, Reza Shabahang ${ }^{*}{ }^{4}$, Farzin Bagheri Sheykhangafshe ${ }^{5}$

1. Ph.D. Student in Clinical Psychology, Faculty of Psychology and Educational Sciences, Kharazmi University, Tehran, Iran

2. B.A. in General Psychology, Faculty of Literature and Humanities, Payame Noor University, Kermanshah, Iran

3. M.A. in Clinical Psychology, Faculty of Psychology and Educational Sciences, University of Tehran, Iran

4. M.A. in General Psychology, Faculty of Psychology and Educational Sciences, University of Tehran, Tehran, Iran

5. Ph.D. Student in Psychology, Faculty of Humanities, Tarbiat Modares University, Tehran, Iran

Citation: Hajialiani V, Tahmasbi A, Shakhs Bolandghadr A, Shabahang R, Bagheri Sheykhangafshe P. Effectiveness of the nurturing program for parents and their children with special needs and their health challenges on the perceived energy for parenting and mindfulness. $\mathrm{J}$ Child Ment Health. 2021; 7(4): 233-247.

URL: http://childmentalhealth.ir/article-1-844-en.html
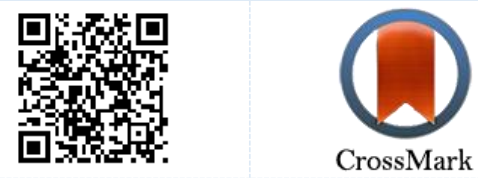

$10.52547 / \mathrm{jcmh} \cdot 7.4 .15$

20.1001.1.24233552.1399.7.4.15.3
A R T I C L E I N F O

\section{Keywords:}

Nurturing program,

perceived energy for

parenting,

mindfulness,

parents and children with

special needs

Received: 5 Jun 2019

Accepted: 8 Dec 2020

Available: 17 Mar 2021

\section{A B S T R A C T}

Background and Purpose: Previous studies indicate the importance of the perceived energy for parenting and mindfulness in the optimal upbringing of children with special needs. In this regard, the present study aimed to investigate the effect of nurturing program for parents and children with special needs and their health challenges on the perceived energy for parenting and mindfulness.

Method: The present research was a quasi-experimental study with pretest- posttest control group design. The population of the study consisted of parents of children with special needs in the exceptional schools of the first district of Rasht city in the first semester of academic year 2019-2020. The sample consisted of 60 parents (mother/father) who were selected by convenience sampling and randomly assigned to the experimental or control group. The applied instruments were Perceived Energy for Parenting Scale (Janisse, Barnett, \& Nies, 2009) and Freiburg Mindfulness InventoryShort Form (Walach et al., 2006). The experimental group, including children with special needs and their parents received twelve sessions of nurturing program for parents and children with special needs and their health challenges (Burton et al., 2018), but the control group did not receive any intervention. Eventually, the data were analyzed by one-way analysis of covariance.

Results: The findings indicated that the nurturing program for parents and their children with special needs and their health challenges had a significant effect on increasing perceived energy for parenting $(\mathrm{F}=80.94)$ and mindfulness $(\mathrm{F}=9.10)(\mathrm{P}<0.01)$.

Conclusion: Considering the importance of perceived energy for parenting and mindfulness in optimal child rearing, the current nurturing program with a focus on attitudes, needs, independence, empathy, and parent-child relationship can be an effective intervention for enhancing perceived energy for parenting and mindfulness in the parents of children with special needs.

* Corresponding author: Reza Shabahang, M.A. in General Psychology, Faculty of Psychology and Educational Sciences, University of Tehran,

Tehran, Iran.

E-mail: Reza.shabahang@ut.ac.ir

Tel: (+98) 2161111

2476-5740/ ( 2021 The Authors. This is an open access article under the CC BY-NC-ND license

(https://creativecommons.org/licenses/by-nc-nd/4.0/). 


\section{Extended Abstract}

\section{Introduction}

Children with disabilities and developmental delays are known as children with special needs. This concept includes a range of disorders in cognitive, physical, motor, verbal and social dimensions (2). One of the most important issues faced by the parents of children with special needs is parenting; specifically the perceived energy for parenting. Perceived energy for parenting is a new concept introduced in relation to the parenting. Like any other social role, parenting requires sufficient energy. In fact, the perceived energy for parenting consists of cognitions, behaviors, and emotions related to parenting, which refer to the physical, cognitive and emotional capacities required to perform parenting duties (10). Parents can suffer from parental burnout, which is characterized by physical and emotional fatigue, emotional distance in parent-child relationship, and feeling inadequate to play the role of a parent (11-15).

Mindfulness is another important issue that can be considered in relation to parents of children with special needs and the children themselves. One of the most characteristic definitions of mindfulness includes awareness arising from purposeful, instantaneous and non-biased attention (18-24). Petcharat and Liehr (20) associate mindful parenting with lower levels of stress, anxiety, and depression, and higher levels of psychological well-being in the parents of children with special needs. Also, findings show the effect of conscious parenting on the increase of acceptance in the children with special needs.

Parents of children with special needs face many difficulties in finding appropriate care for their children (30) and for many reasons; they have limited access to adequate and high-quality care. However, effective interventions can play a very prominent role in improving the family, children and related dimensions (2). Accordingly, the aim of this study was to investigate the effect of parenting and children with special needs and their health struggles on the perceived energy for parenting and mindfulness.

\section{Method}

The present research was a quasi-experimental study with pretest- posttest control group design. The population of the study consisted of parents of children with special needs in the exceptional schools of the first district of Rasht city in the first semester of academic year 2019-2020. The sample consisted of 60 parents who were selected by convenience sampling and then randomly assigned to the experimental or control group. The applied instruments were as follows:

Perceived energy for parenting scale: Janisse, Barnett \& Nies designed this scale to assess parents' energy levels in their parenting roles. The content of the items are based on the literature related to parenting tasks as well as on the assessment of the overall energy metering of McNair et al (10).

Freiburg Mindfulness Inventory-Short Form: Walach et al designed the Freiburg Mindfulness Questionnaire to assess the experience of mindfulness (37). The short form of the Freiburg Mindfulness Inventory is a self-report and one-factor tool that consists of 14 items about mindfulness experience and is scored in 4-point Likert scale from (1) rarely to (4) almost always.

The parenting program for children with special needs and their health challenges (31) belongs to a broader set of parenting programs. In general, this program was designed to substitute dysfunctional parenting of children with special needs with nurturing parenting program. The parenting program for parents of children with special needs and their children includes 12 two-hour group sessions (one session per week). In the first 90 minutes, parents and children were visited separately, and then in the last 30 minutes, parents and children gathered for food and family activities.

\section{Results}

Table 1 shows the mean and standard deviation of pre-test and post-test scores on perceived energy for parenting and mindfulness in the experimental and control groups. Also in this table, the results of Kolmogorov-Smirnov test (K-S Z) are reported to check the normality of the distribution of variables in the two groups. According to this table of $\mathrm{Z}$ 
statistics, the K-S test is not significant for all variables. Therefore, it can be concluded that the distribution of variables is normal.

Table 1. Descriptive Indices of Study's Variables in Experimental and Control Groups

\begin{tabular}{|c|c|c|c|c|c|c|}
\hline Variables & & Groups & Mean & SD & K-S Z & $\mathbf{P}$ \\
\hline \multirow{4}{*}{ Perceived Energy for Parenting } & \multirow{2}{*}{ Pre-test } & Experimental Group & 35.20 & 4.51 & 0.140 & 0.135 \\
\hline & & Control Group & 41.56 & 7.19 & 0.114 & 0.052 \\
\hline & \multirow{2}{*}{ Post-test } & Experimental Group & 48.70 & 4.20 & 0.147 & 0.098 \\
\hline & & Control Group & 45.50 & 6.51 & 0.104 & 0.166 \\
\hline \multirow{4}{*}{ Mindfulness } & \multirow{2}{*}{ Pre-test } & Experimental Group & 31.43 & 5.01 & 0.145 & 0.107 \\
\hline & & Control Group & 39.43 & 4.21 & 0.108 & 0.081 \\
\hline & \multirow{2}{*}{ Post-test } & Experimental Group & 46.80 & 3.41 & 0.145 & 0.111 \\
\hline & & Control Group & 44.01 & 4.31 & 0.105 & 0.094 \\
\hline
\end{tabular}

One-way analysis of covariance was used for each of them to investigate the effect of the nurturing program on the perceived energy for parenting and mindfulness, considering that these two variables are completely separated from each other. Also, before performing the analysis, all the assumptions of oneway univariate analysis of covariance were checked and established.

The results of one-way analysis of covariance to investigate the difference between the experimental and control groups in the perceived energy for parenting showed that the F-statistic was significant at the post-test phase $(53.86, \mathrm{p}<0.001)$. This shows that there is a significant difference between the two groups in terms of the perceived energy for parenting. Also, the effect size of 0.48 showed that this difference was large in the population. The Fstatistic of perceived energy for parenting was significant at the level of 0.001 (80.94).

The results of one-way analysis of covariance to examine the difference of mindfulness between the experimental and control groups showed that the Fstatistic was significant at the post-test phase $(\mathrm{F}=17.89, \mathrm{p}<0.001)$, indicating that there was a significant difference between the two groups in terms of mindfulness. The effect size of .24 showed that this difference was large in the population. The F-statistic for mindfulness at the pre-test phase (9.10) was significant at the level of 0.004. This indicates that pre-test had a significant effect on the post-test scores.

\section{Conclusion}

The results of this study showed that the nurturing program for parents has a significant effect on the perceived energy for parenting of parents of children with special needs. According to the results of the present study, the nurturing program for parents increased the perceived energy for parenting in the participant parents through focusing on the cognitive, social and emotional dimensions (11-15). On the other hand, the nurturing program had a significant effect on the mindfulnes of children with special needs.

These parents mostly have lower level of mindfulness which may cause numerous problems for them and their families. So, it can be concluded that the nurturing program, by emphasizing the acceptance of differences, peace, comfort, achieving peace, grief, and loss in both parents and children, led to an increase in parental awareness (20-24).

One of the limitations of the present study was the lack of continuous assessment of parents during the presentation of the parenting program, which resulted in the lack of full awareness of the impact of each session. It is suggested that next studies assess the parents during the intervention to determine the impact of the program. 


\section{Quarterly Journal of Child Mental Health}

\section{Ethical Considerations}

Compliance with ethical guidelines: This study was conducted independently and is not the result of an approved dissertation or research project. It was conducted with the permission No. 3701/28130/937 dated 30.05.2019 by the Education Administration of District One of Rasht and with the full consent of the sample.

Funding: The present study was conducted without any financial support from a specific organization.

Authors' contribution: : In the present study, the first and second authors participated in the intervention sessions. The third and fourth authors were involved in writing and editing the article, and the fifth author was involved in data collection and analysis.

Conflict of interest: The authors declared no conflict of interest and the results have been reported clearly with no bias. Acknowledgments: We sincerely thank the officials of the exceptional schools in District One of Rasht, the educated and kind parents of children with special needs, and the children participating in the research. 


\section{اثربخشى برنامه يرورشى والدين و كودكان با نيازهاى ويزه و كشاكشهاى سلامتى آنها بر انرزى ادراكى شده والدكرى و ذهن آكاهى}

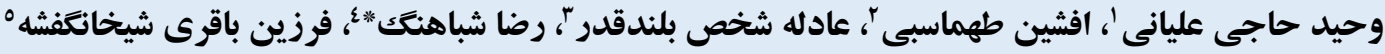

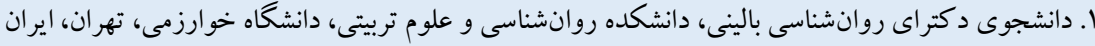

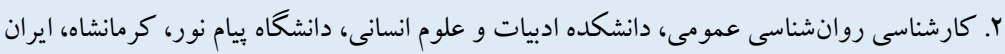

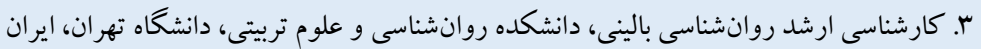

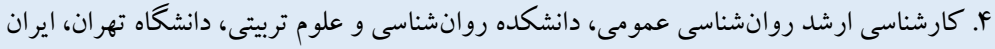

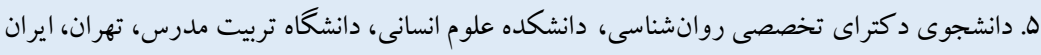

\begin{tabular}{|c|c|}
\hline جكيده & 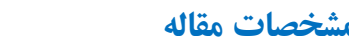 \\
\hline زمينه و هدف: نتايج يزوهشهاى بيشين حاكى از اهميت انرزى ادراكى شده والدگرى و ذهن آكاهى در يرورش مطلوب كود كان با & كليدوازهها: \\
\hline نيازهاى ويزٌه است. در اين راستا، مطالعه حاضر با هدف بررسى تأثير برنامه يرورشى والدين و كود كان با نيازهاى ويزُه و كشاكشهاى سلامتى & 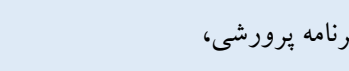 \\
\hline آنها بر انرزى ادراك شده والد گرى و ذهن آكاهى انجام شده است. & 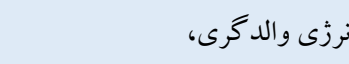 \\
\hline 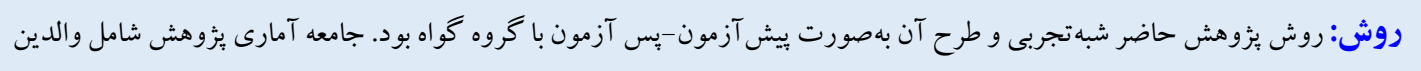 & 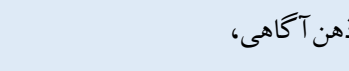 \\
\hline 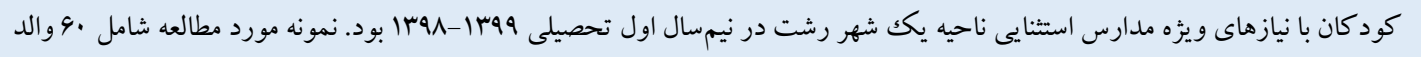 & إلد الدين و كود كان با نيازهاى ويزه \\
\hline (مادر يا بدر) بودند كه با استفاده از روش نمونه گيرى در دسترس انتخاب و به صورت تصادفى در دو گروه آزمايش و گروه گو اه جايدهى & \\
\hline 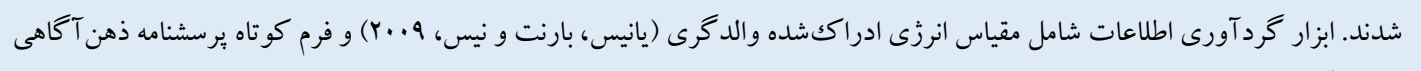 & \\
\hline فرايوركى (والاج و همكاران، و..r) بود. كروه آزمايش شامل والدين كودكان با نيازهاى ويزه به همراه فرزندانشان، دوازده جلسه برنامه & \\
\hline 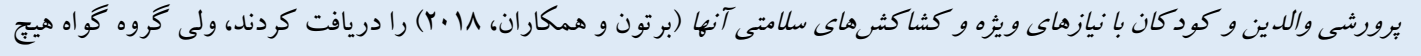 & \\
\hline مداخلهاى دريافت نكردند. در بايان دادههاى به دست آمده با آزمون تحليل كوواريانس تككمتغيره يكراهه تحليل شدند. & \\
\hline يافته ها: نتايج نشان داد كه برنامه يرورشى والدين و كودكان با نيازهاى ويثره و كثاكشهاى سلامتى آنها بر افزايش انرزى ادراكك شده & \\
\hline 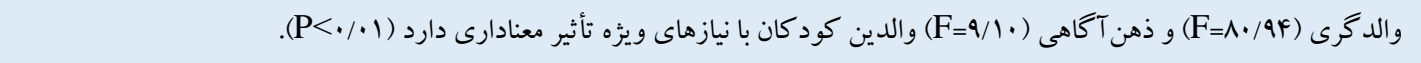 & \\
\hline نتيجه كيرى: با در نظر گرفتن اهميت والد گرى و ذهن آكاهى در يرورش مطلوب، برنامه يرورشى حاضر با تمركز بر نخرشها، نيازها، & 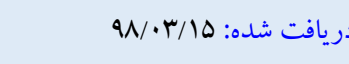 \\
\hline استقلال، همدلى و ارتباط والد- فرزند مى تواند مداخلهاى كار آمد در بهبود انرزى ادراكى شده والد گرى و ذهن آكاهى والدين كود كان با & 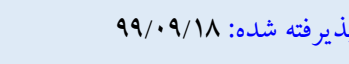 \\
\hline 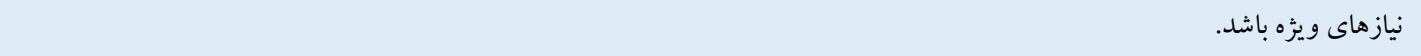 & 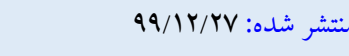 \\
\hline
\end{tabular}

* نويسنده مسئول: رضا شباهنگ، كارشناسى ارشد روانشناسى عمومى، دانشكده روانشناسى و علوم تربيتى، دانشكاه تهران، ايران.

Reza.shabahang@ut.ac.ir

تلفن: 
نقش والدگرى است (1). با توجه به مشخصههاى خانو ادههاى كود كان با نيازهاى ويزه، مشـكلات والدكرى در اين دســـه از خانو ادهها تقريباً

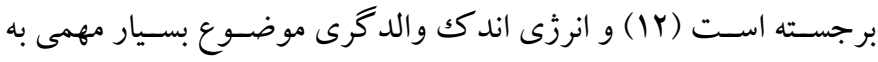

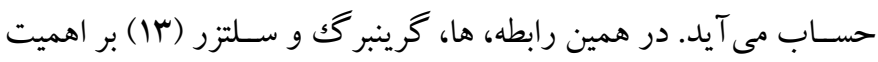

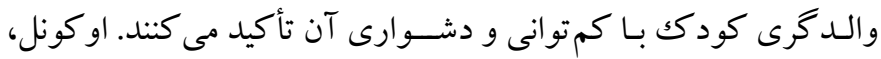

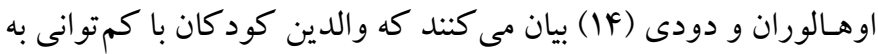

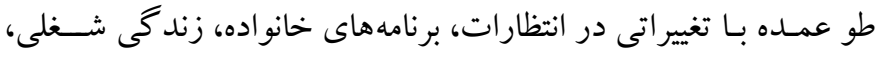
وضسيعت اجتماعى و اقتصـادى، و همجنين سـلامت خود مو اجه مىشوند

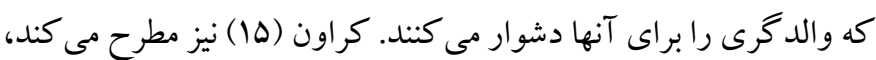
والدگرى كودكك با كمتوانى تحولى، تجربه يِيجيدهاى است كه با ترديد، وحشت و احساس از دست دادن همراه است. همجنين گرين و زج (19) كزارش مى دهند كه والدين كود كان با نيازهاى ويزٔه در مقايسـه با سـاير

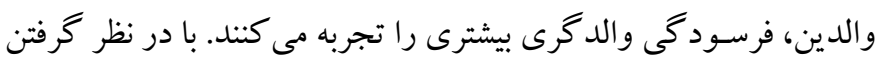

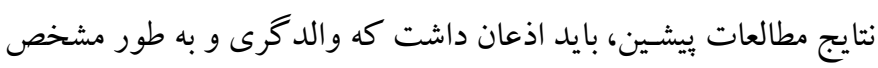

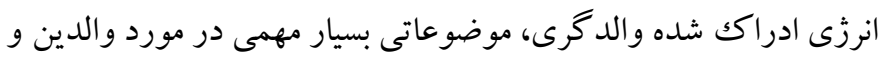
كود كان با نيازهاى ويزه هستند. بدين معنا كه والدين كود كان با نيازهاى

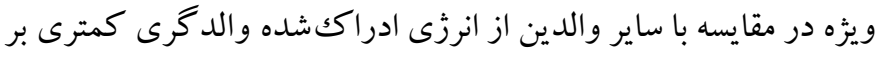

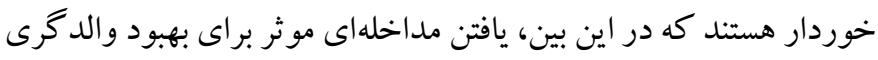

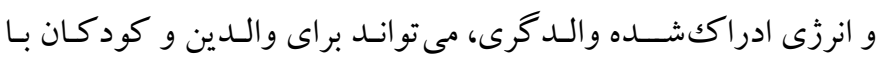
نيازهاى ويزهه بسيار مفيد باشد.

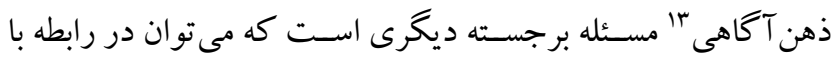

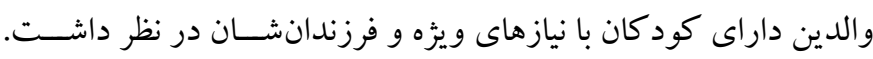

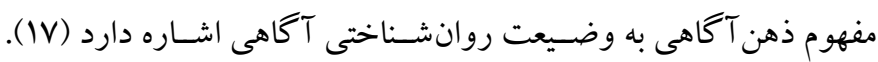

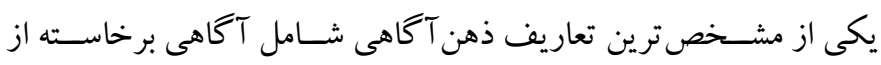

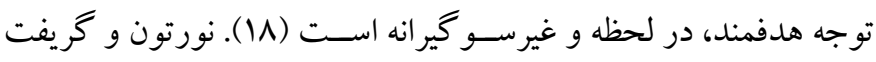
(19) ذهن آكاهى را به صورت مشاهده غيرسو گيرانه جريان محر ككهاى

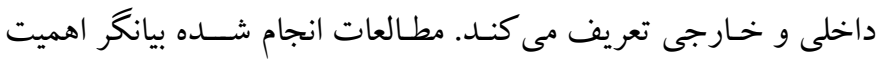

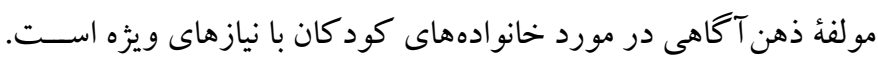

8. Children with special needs

9. Euphemism

10. Parents have children with special needs

11. Perceived energy for parenting

12. Parental burnout

13. Mindfulness
مقدمه

بر طبق آمار ســازمان جهانى ســلامت'، بر آورد مى شـــود كه هو ميليون

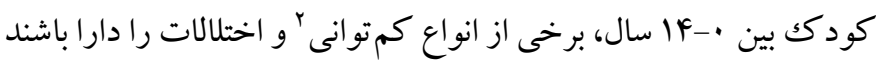

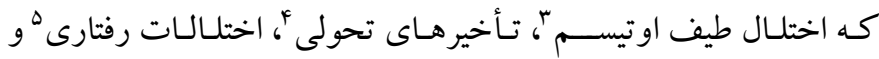

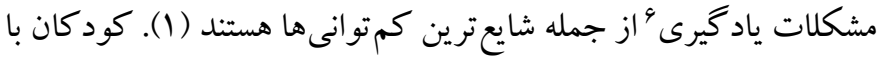

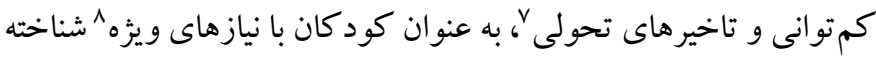

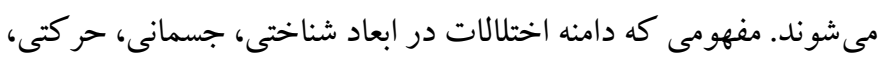

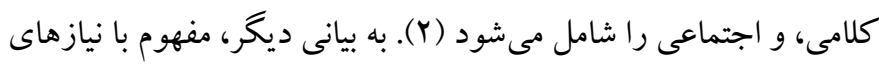
ويزه، معادل ملايم و غيرمسـتقيم "مفهوم كمتو انى اسـت كه كه به دارا بودن

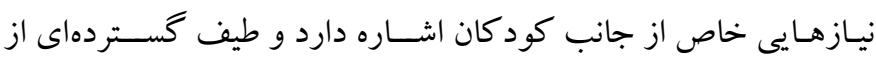

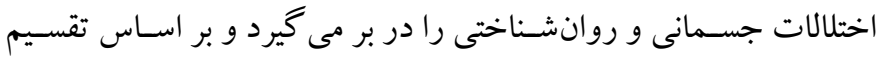
بندى هاى مختلف بايد توجه شود كه گروه تيزهوشان و با استعداد نيز در فهر ست افراد با نيازهاى ويزه قرار دارند (r). از جمله موضــوعات بسـيار مهم در مورد والدين داراى كود كان با تهريا

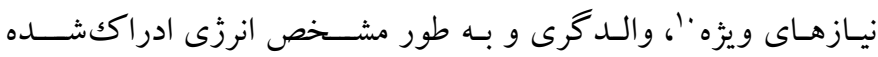

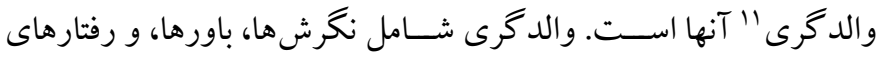
والدين اسـت (F) و عاملى بسيار مهم و تأثير گذار در سلامت (ه)، تحول

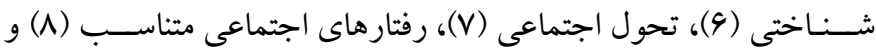

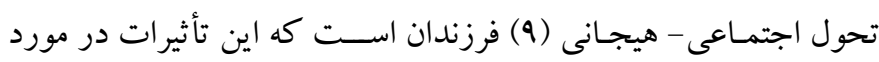

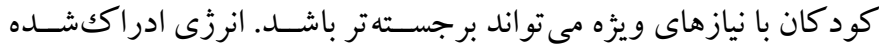
والدگرى از جمله مفاهيم جديدى اسـت كه در رابطه با والدگرى مطرح

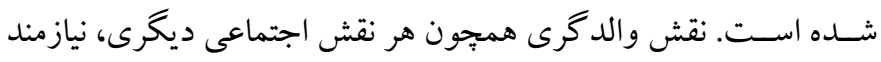

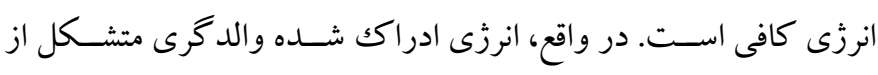

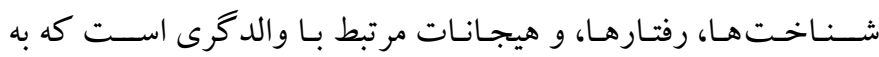

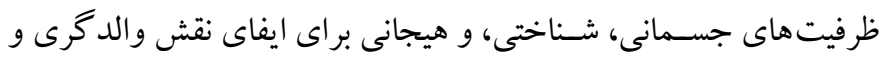

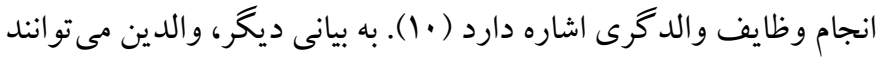

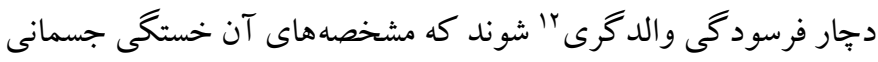
و هيجانى، فاصله گيرى هيجانى از فرزند، و احساس عدم لياقت در در ايفاى

1. World Health Organization

2. Disability

3. Autism spectrum

4. Developmental delays

5. Behavioral disorders

6. Learning problems

7. Children with developmental disabilities 
برجّــبـهاى اجتماعى مواجه مىشـوند كه مى تو انند نشـانه هاى سـلامت جسمانى، عواطف منفى و بهزيستى روانشناختى كمتر را در اين دسته از

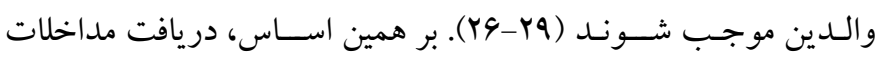
كار آمد مى توانند بر سلامت والدين و كود كان با نيازهاى ويزه آنها تأثير باشــد. والدين كود كان با نيازهاى ويزٔه، با كشاكثهاى بسيارى در يافتن مر اقبت هاى مناسـب بر ایى فرزندانشـان مواجه مى شـوند ( •r) و به دلايل بسـيار، دسـترسـى محدودى به مراقيتهاى كافى و با كيفيت دارند؛ در حالى كه مداخلات كار آمد مى توانند نقشــى بســيار برجســه در بهبود خانواده، فرزندان و ابعاد مرتبط با آنها داشته باشند (Y). بـا توجـه بـهـ وجود مشــكلـاتى در انرزى ادراككشـــــه والـدكرى و ذهن آكاهى والدين كود كان با نيازهاى ويزه، برنامه برورشـى والدين و كود كان با نيازهاى ويزه و كشاكش هاى سلامتى آنها به عنوان مداخلهاى گسترده و جديد مى تواند روشى كار آمد و مفيد براى و الدين و كود كان با نيازهاى ويزه آنها باشــد. برنامه يرورشـى در نظر دارد كه تحول بهينه خانو اده كود كان با نيازهاى ويزه را از طريق كمكك به آنها براى دستيابى به نخرش هاى مثبت، استقلال، بارورى و در آميختخى، موجب شود. برنامه يرورشى والدين و كود كان با نيازهاى ويزه و كشاكشهاى سلامتى آنها بخشى از مجموعه كستردهترى به نام برنامه هاى برورش والدگرى ' است

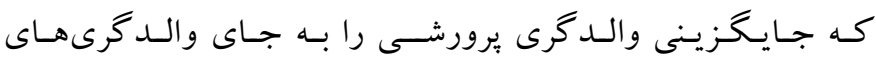

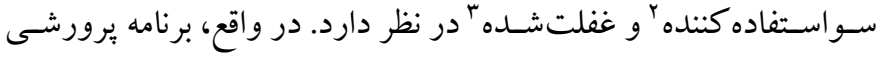
متكى بر نظريه مراقبت خانو ادهمحور (خانواده بخش اصسلى در تحول و مـوفــــت كودك اســت )، نـظريسه آدلرىه (هر كودكى فـارغ از

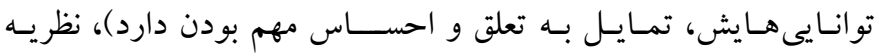
زبيستى عصبى بين فردى (نقش ارتباطات بينفردى در شكل دهى مغز ) و نظريه دلبستخى (جّكو نكى ارتباط والد و فرزند و بيامدهاى آن) است و مداخلهاى است كه به صورت همزمان والدين و كود كان با نيازهاى ويزه را مورد هـدف قرار مىدهـد تا افز ايش قدرت خانو اده ل را موجب شـــود ( آM). با توجه به مشـخصـه هاى برجسـته برنامه يرورشى هميجون تأكيد بر نكرش، همــلى و ارتبـاط والـد-فرزنسد، تمركز بر هر دو والـدين و
يتجارات و ليهر (·r) عنوان مى كنند كه والدگرى ذهن آ گاهانه با سطوح يايين تر تنش، اضـطراب، افسردگى و سـطح بالاتر بهزيستى روانشناختى والـدين كودكـان با نيازهاى ويثزه مرتبط اســت. همجنين نتايج حاكى از تأثير والدگرى ذهن آكاهانه بر بذيرش بيشـتر فرزند با نيازهاى ويزه خود بود. ويتينكهام (Y) با بررسى مطالعات انجام شده درباره تأثير مداخلات والدگرى موج ســوم با تأكيد بر ذهن آكاهى و يذيرش، بيان مى كند كه ذهن آكَاهى و يـــيرش، عو املى مهم در خانو ادههاى كود كان با نيازهاى ويزه اســت. نتـايج مطـالعه جان و لام (YY) نشــان مىدهد كه والدكرى كودك كم توان ذهنى و با مشـكلات رفتارى، الزاماً به معناى تنش بيشـتر نيسـت و در اين بين ذهن آكاهى عاملى بسيار با اهميت به حساب مى آبد. در واقع، والـدين كودكـان بـا نيـازهاى ويزه به طور عمده از ذهن آكاهى كمترى برخوردار هســتــد كه اين مســـله منجر به تنش بيشــتر در آنها مىشـود. هم راسـتا با مطالعات ديخر، مككدونالد و هسـينگك (سY) نيز بر نقش ذهن آكَاهى در خـانو اده كود كـان بـا نيازهاى ويزٔه تأكيد مى كنند؛ بدين مفهوم كه سـطوح كمتر ذهن آكاهى نسـبت به والدكرى در يدران كودكـان بـا نيـازهـاى ويثزه، بـه كـاهش در آميختخى بـا فرزنـدان منجر مىشــود. همجنين رايـان و احمـــ (YF) منطبق بـا مطـالعـه مرورى خود گز ارش مىدهند كه ذهن آكاهى موضوعى اساسى در والدگرى كود كان با نيازهاى ويزٔه است و مداخلات ذهن آكاهى بر تنش والدين اين دسته از كود كان مؤثر اســت. با توجه به نتايج بزووهش هاى بيشــين، ذهن آ كاهى مسئله ديخرى است كه در رابطه با والدين كود كان با نيازهاى ويثه، بسيار اهميت دارد و سـطوح كمتر ذهن آكاهى در آنها برجسـته اسـت. بر اين اساس، ارائه مداخلهاى در رابطه با ذهن آكاهى والدين كود كان با نيازهاى ويزٔه مى توانــ تـأثيرات مثبتى بر روى خـانو اده كودكـان با نيازهاى ويزه بكَارد.

در مجموع، نكهـدارى و يرورش كودكـان با نيازهاى ويزّه، مىتواند ييامدهاى منفى مشخصى را براى سلامت جسمانى و روانشناختى والدين به همر اه داشته باشد (rا-Uه). در واقع، والدين كود كان با نيازهاى ويثه، با كشــاكش هاى همجيون مشــكلات اقتصــادى، رفتارهاى مشــكل زاو و

1. Nurturing parenting programs

2. Abusive

3. Neglectful

4. Family centered care 
علاقمندى به شـركت در مطالعه و رضـايت شـخصسى بودند. ملاكك هاى ورود به يزٔوهش براى كود كان نيز شـامل سـن والدين، تحصسيلات و سن والدين، رضـايت كتبى، زندكى با والدين، دامنه سـنى 9 تا ها ســال و بررسى يرونده دانش آموز جهت شدت اختلال بود. هميجنين، غيبت بيش

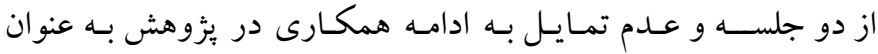
ملاككهاى خروج شـركت كنند كان در نظر گرفته شـدند. ميانخين سـنى

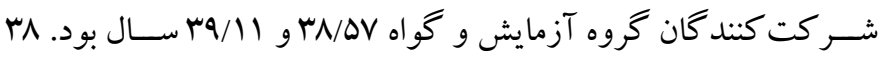
درصـد از والدين داراى شـغل دولتى و بو درصسـ نيز داراى شـغل آزاد بودند. از نظر سـطح تحصيلات، 1 | درصد زير دييلم، سه درصد دييلم، و وץ درصد نيز دار اى تحصيلات دانشخاهى بودند. همجنين، ميانگين سطح در آمدى خانو ادهها نيز نزديكك به دو ميليون تومان بود.

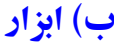

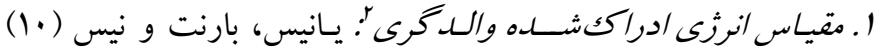
مقياس انرزى ادراككشـده والدگرى رابراى ارزيابى سطح انرزى والدين در ايفـاى نقش والـدكرى، طراحى كردهانـد. محتواى گويههاى مقياس انرزى ادراككشـده والدگرى بر اساس مطالعه بيشينهاى يزوهشى مرتبط

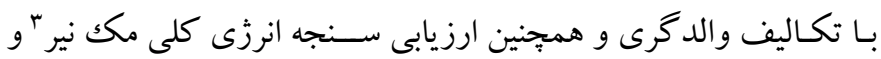
همكاران تدوين شدند (مثل؛ من از ورزش كردن و فعاليتهاى جسمانى با فرزندم لذت مىبرم). اين مقياس تككعاملى و متشكل از · ا اكويه است كه، بـه صــورت ليكرت و كزينسهاى از كاملاً مخالفم تا كاملاً موافقم ياســخدهى و نمرهدهى مى شـود. حداقل و حداكثر نمره در اين مقياس به ترتيـب · ا و ·9 اســت كـه نمرات بالاتر، حاكى از انرزى ادراككشـــه والدگرى بيشـتر است. يانيس، بارنت و نيس ( •(1) همسانى درونى مقياس

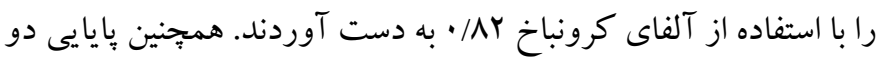
نيمهسـازى مقياس •^/1 · به دست آمد. به منظور سـنجش روايى افتراقى مقياس، تحليل ســاختارى بر روى گويههاى مقياس انرزى ادراككشــده والدگرى، بر آورد فعاليت والدگرىه و سنجه نيمرخ وضيعت هاى خلقى انجام شد. يافته ها بيانكر روايى افتر اقى مناسب مقياس بود؛ همبجنين روايى همخر ايى اين ابزار بـا توجـه بـه محاســبه همبســــى مثبت آن با فعاليت

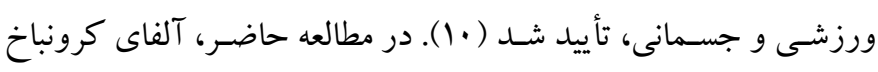

4. Differential validity

5. Parenting activity estimates

6. Profile of mood states inventory
فرزندانشــان و همجينين ارزان و كو تاهمدت بودن آن، مىتوان از برنامه يرورشــى بـهـ عنو ان مـداخلـهاى كـار آمــد براى خـانو ادههاى كود كان با نيـازهاى ويزه بهره برد. بدين مفهوم كه با در نظر كرفتن تأثير مؤلفههايى همجون شـناخت مثبت، اسـتقلال، همدلى و در آميختخى بر والدگرى و ذهن آكاهى (צ-Y-YM)، برنامه يرورشسى مىتواند مداخلهاى بسيار كار آمد بر اي افزايش انرزى ادراكك شده والدكرى و ذهن آكاهى والدين كود كان با بازهاى ويزّه باشد.

از اين رو، بررسـى اين موضـوع كه آيا برنامه يرورشــى مى تو اند بر

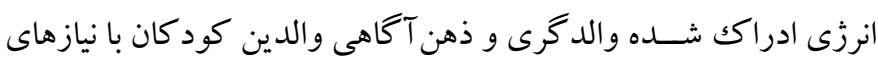
ويزه تأثير بكذارد يا خير، بسيار مهم است. با توجه به فقدان مطالعهاى در مورد برنـامسه يرورشــى در داخـل كشــور و همجنين بـا در نظر كرفتن مطالعات اندكك انجام شـــه درباره تأثيرات برنامه يرورشــى در خارج از كشـور، يثوهش حاضر در آكَاهى بهتر از برنامه يرورشى و يِيامدهاى آن مى تواند بسـيار كمكك كننده باشد. بر اين اساس، هدف از ئزوهش حاضر بررسـى تـأثير برنسامه برورشـى والدين و كود كان با نيازهاى ويزه و كشـاكش هاى سلامتى آنها بر انرزى ادراككشده والدكرى و ذهن آكاهى

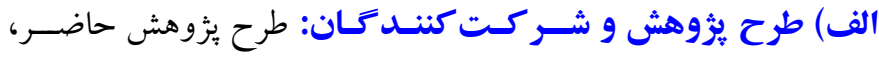
شـــــه تجربى بـا طرح بيش آزمون-يس آزمون بـا كروه گو اه بود. جـامعه آمارى بئوهش شـامل والدين كود كان با نيازهاى ويثزه (طيف اوتيســم، كم توانى ياد گيرى، نشــانگگان داون، و نارســايى توجه- فزون كنشــى ') مدارس اسـتنايى ناحيه يكك شهر رشت در نيمسـال اول تحصسيلى سـال

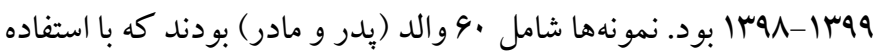
از روش نمونه كيرى در دسـترس انتخاب و به صـورت تصـادفى در دو كروه آزمايش ( •rنفر) و كو اه (·r نفر) جايدهى شدند. ملاككهاى ورود بـه يثزوهش براى والـدين كودكـان شــامـل تعلق به جامعه يثوهش، نبود مشـكلات جسـمانى و روانشـناختى جدى گز ارش شـده (بررسى يرونده يزشـكى)، دارا بودن سـواد خواندن و نوشـتن، دامنه ســى بين ·س تا لها،

1. Attention Deficit Hyperactivity

2. Perceived energy for parenting scale

3. McNair 
روايى همزمان مناسـب يرسشنامه را زَارش كردند. همجينين نتايج بيانگر

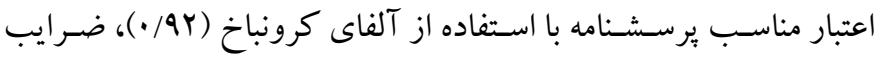

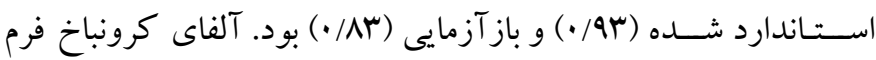

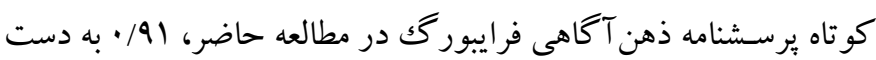
آمد كه حاكى از همسانى درونى مناسب يرسشنامه است. ج) برنامه مداخلهاى: برنامه يرورشى والدين و كود كان با نيازهاى ويزه

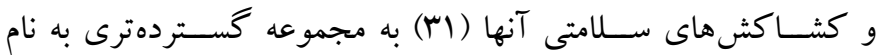

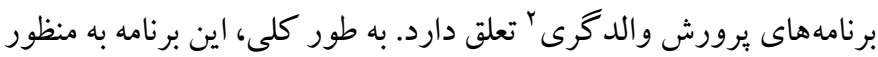

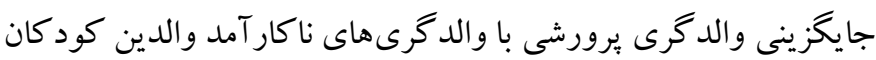
با نيازهاى ويزه طراحى شــــ. برنامه برورشسى بر نظريه مراقبت خانواده محورّ"، نظريـه آدلرى"، نظريه زيسـتى - عصسبى بين فردى"، و نظريه

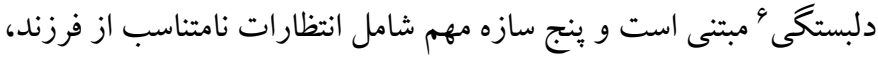

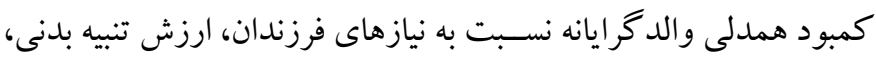

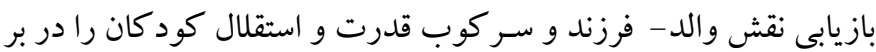

براى مقياس انرزى ادراككشـده والدگرى، 9^/• به دسـت آمد و روايى آن را متخصصان تأييد كردند.

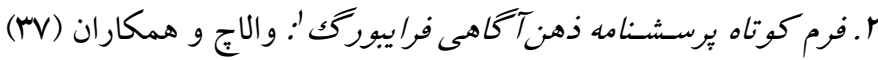

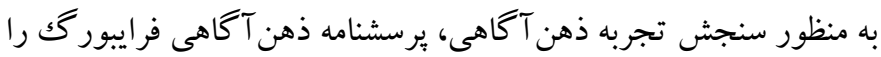
طراحى كردند. فرم كوتاه يرسـشــنامه ذهن آكاهى فرايبورگك، ابزارى خود گزارشى و تككعاملى است كه متشكل از أ كويه در مورد تجارب

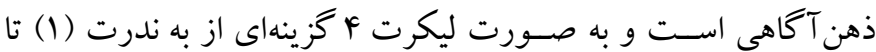

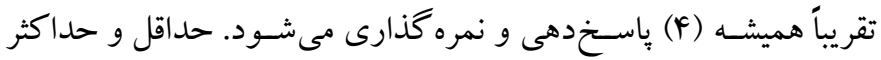

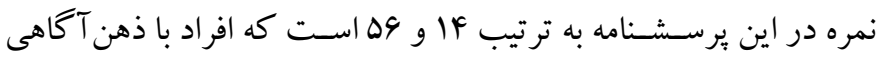
بيشتر، نمرات بيشترى در اين برسشنامه كسب مى كنند. والإ و همكاران با بررسى نسخه كو تاه يرسشنامه، ساختار تككعاملى و مشخصه هاى (TV) روانسـنجى منـاسـب آن را گز ارش كردند. آلفاى كرونباخ و ميانكين

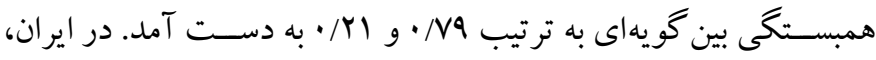

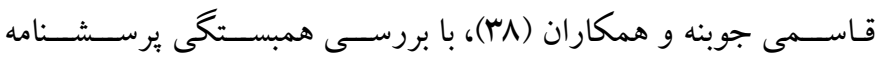

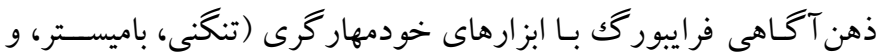

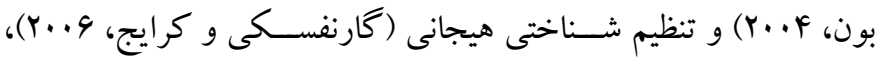

جدول ا: محتواى جلسات مداخله

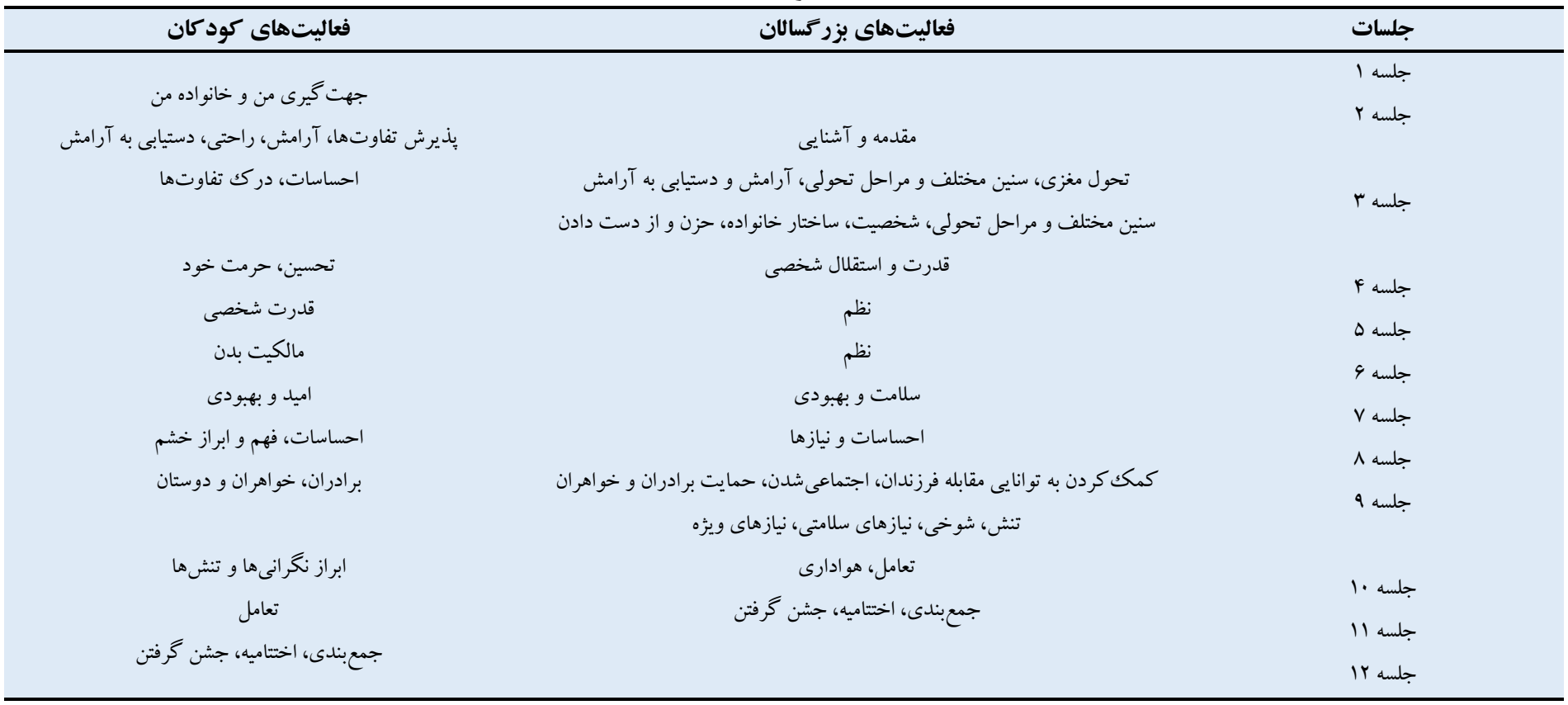

4. Adler theory

5. Interpersonal neural biological theory

6. Attachment theory
1. Short form of Freiburg mindfulness inventory

2. Parenting programs

3. Family-centered care theory 
محتو اى جلسات مداخله ارائه شده است. همجنين به منظور رعايت نكات

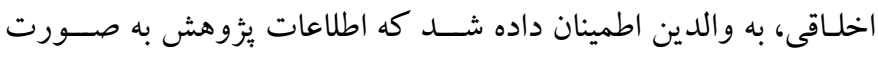

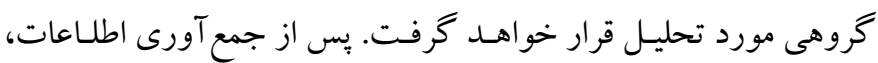

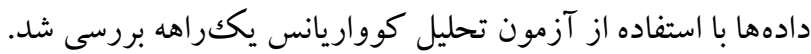

\section{يافته ها}

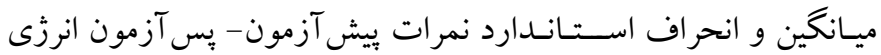

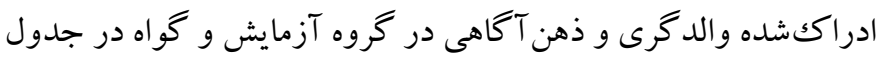

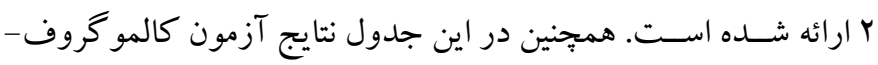

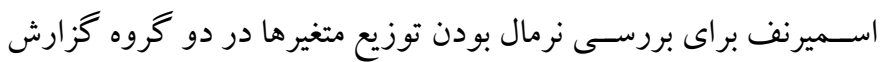

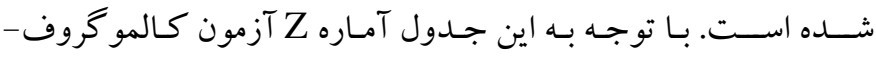
اسـميرنف براى تمـامى متغيرها معنادار نيســ، در نتيجه مى توان نتيجه

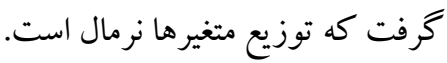

د) روش اجرا: بِ از همـاهنكى ها و اخذ مجوز از ســازمان آموزش و

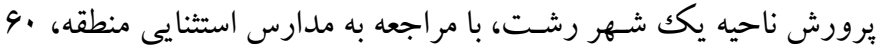

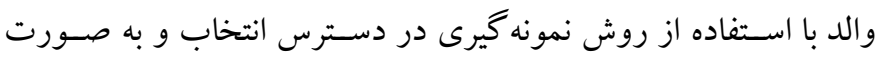

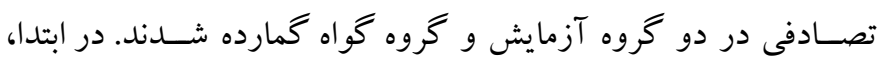
توضـيحاتى كلى به والدين داده شــد و پس از در نظر كرفتن ملاككهاى

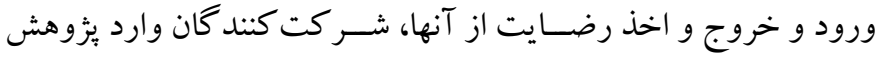

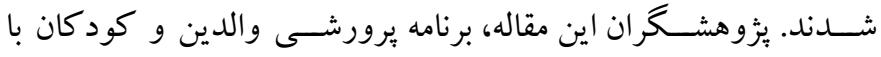

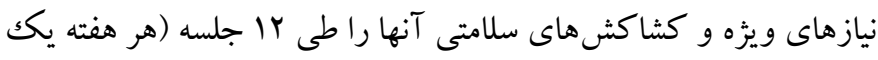

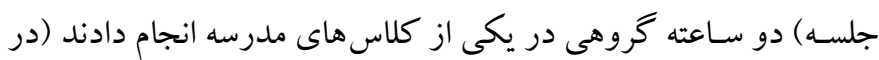

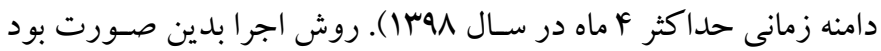

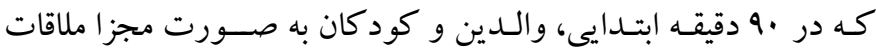

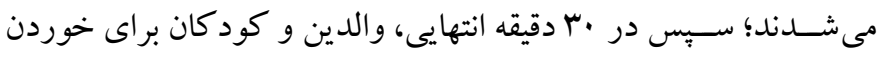

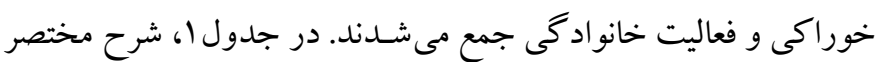

جدول ז: شاخصهاى توصيفى نمرات ييشآزمون و يس آزمون در دو كروه آزمايش و كواه ( • نفر)

\begin{tabular}{|c|c|c|c|c|c|c|}
\hline سطح معنادارى & K-S Z & انحراف استاندارد & ميانكين & تروه & وضعيت & متغير \\
\hline . &.$/ / 4$. & $F / \Delta)$ & $r \Delta / r$. & آزمايش & \multirow{2}{*}{ ييش آزمون } & \multirow{4}{*}{ انرزى ادراكششده والدگرى } \\
\hline.$/ . \Delta r$ &.$/ 11 F$ & $V / 19$ & $|4| / \Delta 9$ & كواه & & \\
\hline.$/ .91$ &.$/ I F V$ & $f / r$. & FN/V. & آزمايش & \multirow{2}{*}{ يَس آزمون } & \\
\hline.$/ 194$ & $\cdot / 1 \cdot F$ & $9 / 01$ & $\varphi \Delta / \Delta$. & كواه & & \\
\hline$\cdot / 1 \cdot v$ &.$/ I F \Delta$ & $\Delta / \cdot 1$ & $M / / F r$ & آزمايش & \multirow{2}{*}{ يِش آزمون } & \multirow{4}{*}{ ذهن آ كاهى } \\
\hline$\cdot / \cdot 11$ & $\cdot / 1 \cdot 1$ & $F / r I$ & ra/va & كواه & & \\
\hline.$/ 111$ & . /IFS & $r / F i$ & $\forall \& / \Lambda$. & آزمايش & \multirow{2}{*}{ ي بس آزمون } & \\
\hline.$/ .94$ & $\cdot / 1 \cdot \Delta$ & F/M & $F F / \cdot 1$ & كواه & & \\
\hline
\end{tabular}

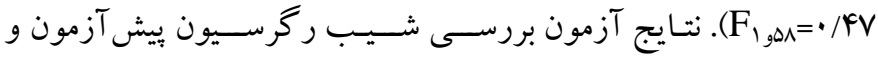
يس آزمون ذهن آكاهى در كروه آزمايش و كواه، نشــان داد كه شــيب

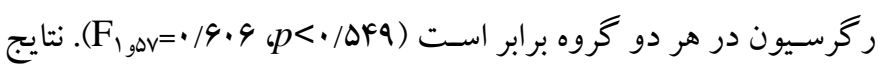
آزمون لوين براى بررسى همخنى واريانس متغير وابسته در گرووها نشان

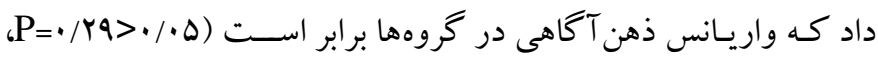
r//1/ بررسـى تفاوت كروههاى آزمايش و گُ اه در بيش آزمون و بس آزمون. متغير انرزى ادراككشده والدكرى و ذهن آكاهى گزارش شده است.
براى بررسى تأثير برنامه يرورشى والدين و كود كان با نيازهاى ويثه

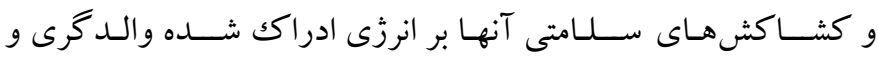
ذهن آكاهى با توجه به اينكه اين دو متغير كاملا از يكديخر مجزا هسـتند، براى هر كدام از آنها از تحليل كوواريانس تككمتغيرى يككراهه اسـتفاده شد. نتايج آزمون بررسى شيب رگرسيون بيش آزمون و يس آزمون انرزى

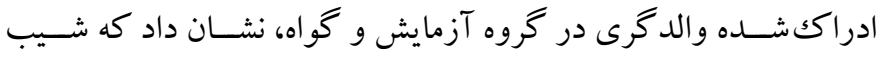

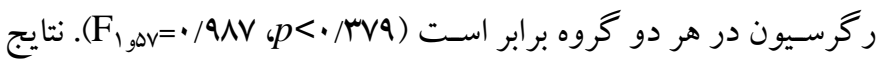
آزمون لوين براى بررسى همخَى واريانس متغير وابسته در گرووهها نشان

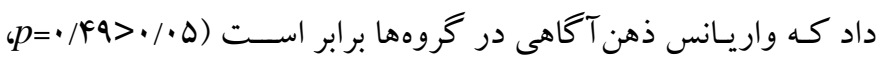


جدول ": نتايج تحليل كوواريانس تكمتغيرى براى بررسى تفاوت كروه آزمايش و كواه در انرزى ادراكى شده والدكرى

\begin{tabular}{|c|c|c|c|c|c|c|}
\hline اندازه اثر & سطح معنادارى & Tاره F & ميانتين مجذورات & درجه آزادى & مجموع مجذورات & منبع \\
\hline .194 &.$/ \cdot 1$ & $\Leftrightarrow 9 / 00$ & $11 V 0 / 94$ & $r$ & $11 V \Delta / 99$ & الكوى اصلاح شده \\
\hline$\cdot / \Delta \Lambda$ & $\% \cdot 1$ & $\Lambda \cdot / 9 F$ & $1 . r Y / .4$ & 1 & $1 . Y Y / .9$ & ي بيش آزمون \\
\hline \multirow[t]{2}{*}{$\cdot / 4 \Lambda$} &.$\cdot \cdot 1$ & $\Delta r / \Lambda Q$ & $91 \cdot / 10$ & 1 & $91 \cdot / 10$ & عضويت گروهى \\
\hline & & & $\mid Y / G Y$ & $\Delta V$ & VI9/Vr & خطا \\
\hline
\end{tabular}

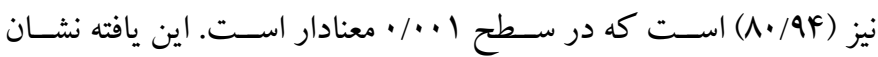
مى مهد كه بيش آزمون تأثير معنادارى بر نمرات يس آزمون دارد.

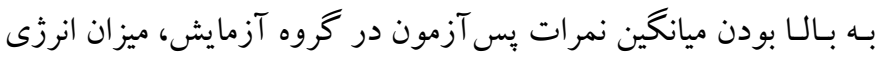

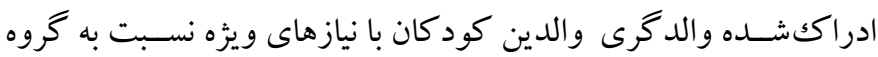
كواه افزايش يافته است.

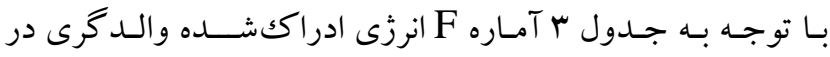

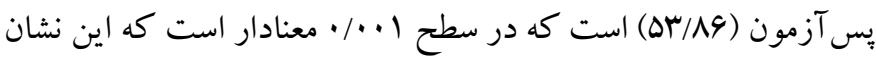

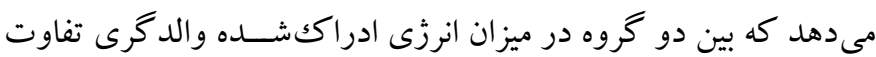

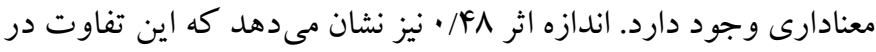

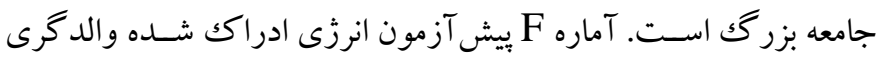

جدول ع: نتايج تحليل كوواريانس تك متغيرى براى بررسى تفاوت كروه آزمايش و كواه در ذهن آكاهى

\begin{tabular}{|c|c|c|c|c|c|c|}
\hline اندازه اثر & سطح معنادارى & T Fاره & ميانكين مجذورات & درجه آزادى & مجموع مجذورات & منبع \\
\hline$\cdot / r \mu$ &.$/ .1$ & $\Lambda / 9 V$ & $119 / Y F$ & $r$ & $119 / Y F$ & الكوى اصلاحشده \\
\hline$\cdot /$ If & 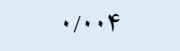 & $9 / 1$. & $1 r \cdot / 19$ & 1 & $1 r \cdot / \wedge q$ & بيش آزمون \\
\hline \multirow[t]{2}{*}{$\cdot / T_{F}$} & $\% \cdot \cdot 1$ & IV/Aq & THVIAV & 1 & TMV/AV & عضويت گروهى \\
\hline & & & $1 r / r q$ & $\Delta V$ & $V \Delta V / q 1$ & خطط \\
\hline
\end{tabular}

انرزى ادراككشـــه والدگرى و ذهن آكاهى والدين كود كان با نيازهاى

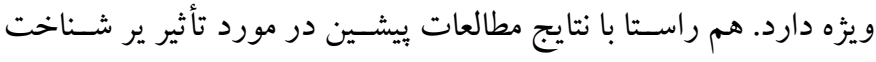

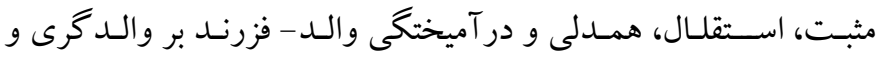

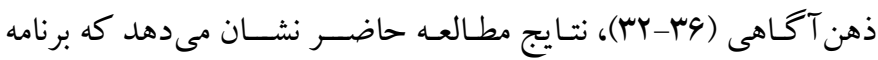

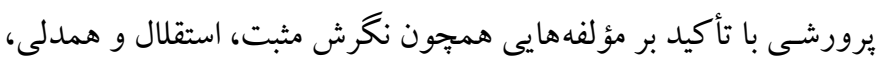

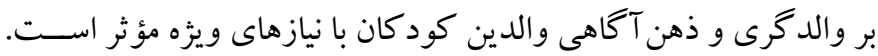
همجنين يافته هاى بزؤهش حاضر به طور مشخص با نتايج مطالعه برتون و

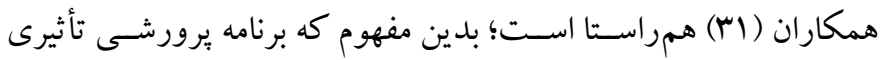

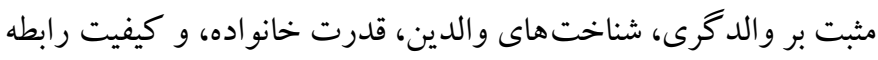

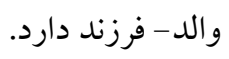

بر اسـاس مطالعات بيشـين، بايد اظهار داشت كه يرورش و نخهمارى

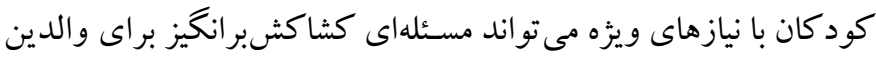

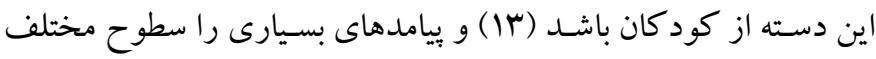

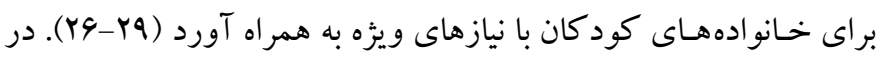
اين بين، انرزى ادراككشـــه والـدگرى و ذهن آكاهى از جمله مهم ترين
بـا توجـه بـه جـدول F آمـاره F ذهن آكاهى در يس آزمون (IV/A9)

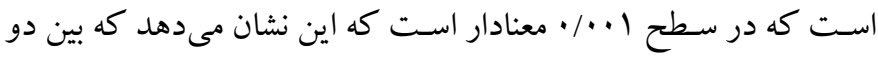

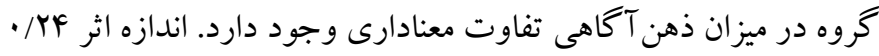

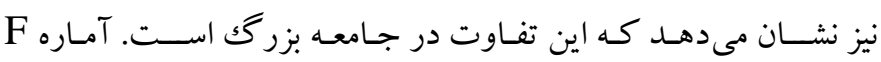

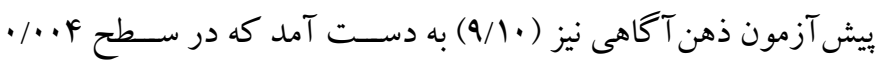

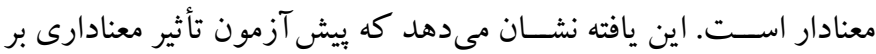

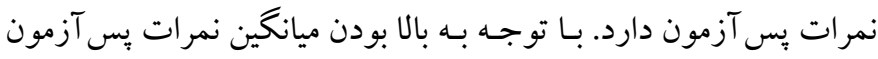

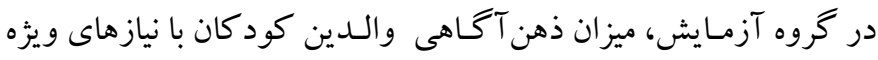

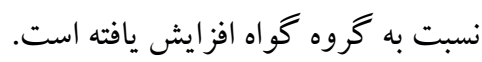

\section{بحث و نتيجه كيرى}

يزّوهش حاضر با هدف بررسى تأثير برنامه يرورشى والدين و كود كان با بيا

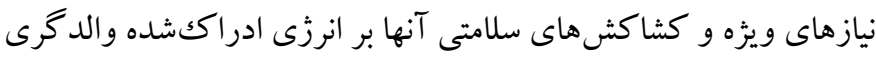

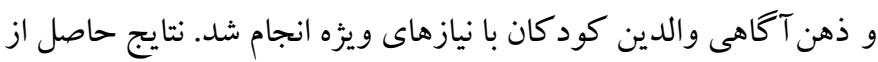

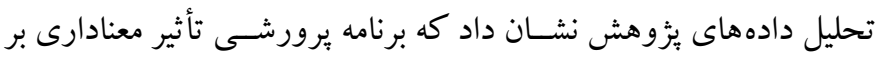


منجر به افزايش ذهن آكاهى در والدين شد؛ به بيانى ديخر، برنامه مداخله

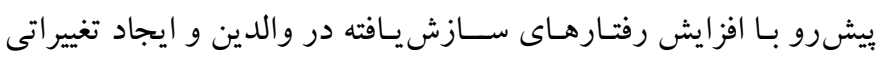

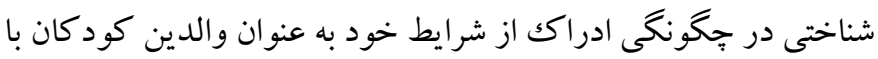

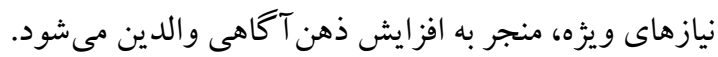

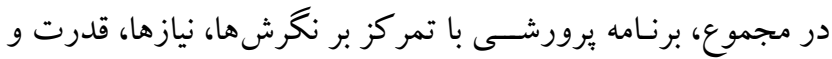

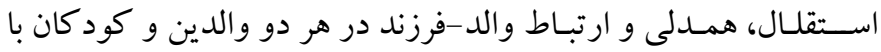
نيـازهـاى ويزه آنها، منطبق بـا نتايج مطالعـات بيشـين در مورد ارتباط

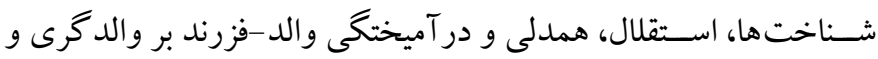

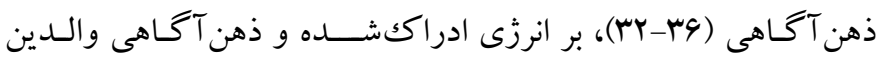

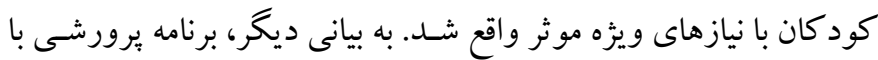

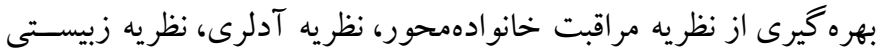

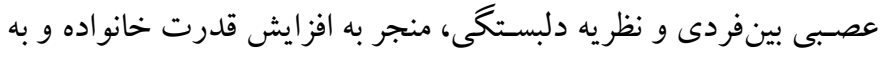

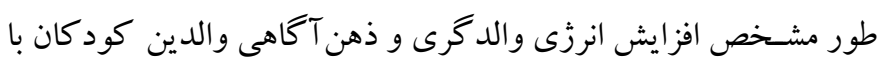

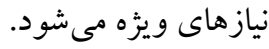

از محدوديت هاى بثزوهش حاضـر، عدم ســنش مداوم والدين در طول ارائه برنامه يرورشسى بود كه منجر به عدم آكاهى كامل از تأثير هر

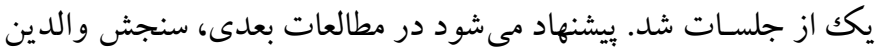

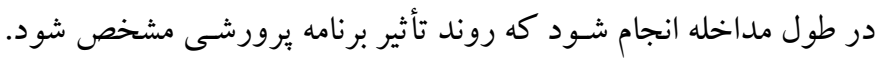
عدم كنترل موضسوعات بسـيار مهم مر تبط با فرزندان همجون نوع نون اختلال

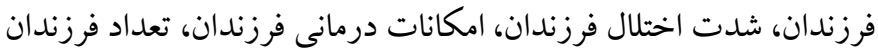

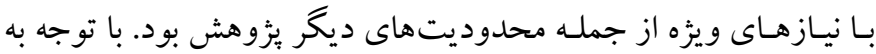
تأثير برنامه يرورشسى بر هر دو والدين و فرزندانشـان، عدم ارزيابى تأثير

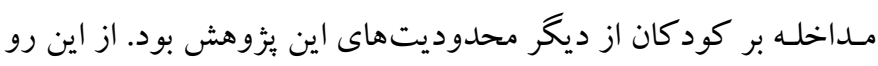
بيشـــهـاد مىشـــود كـه يزوهش هـاى بعدى علاوه بر ارزيابى تاثير برنامه

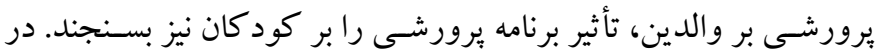

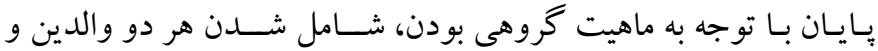

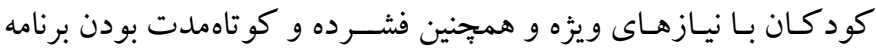
يرورشى به كار رفته شده در اين مطالعه، توصيه مى شود كه سازمانهاى

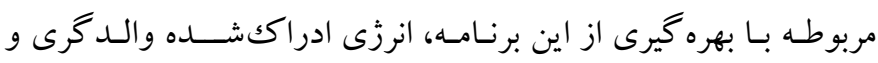
ذهن آكاهى رادر والدين كود كان با نيازهاى ويزه بهبود دهند.
مسـائلى هسـتند كه در رابطه با خانواده كود كان با نيازهاى ويزه مىتوان مطرح كرد.

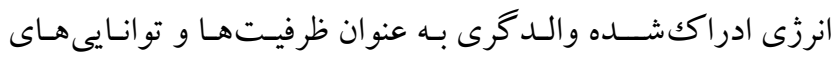

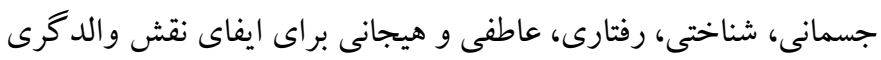

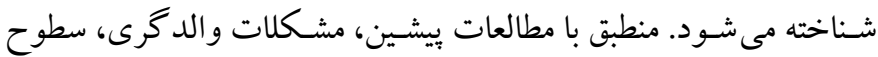

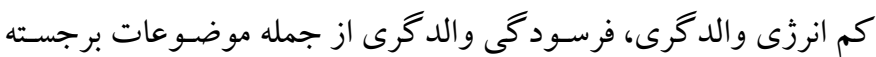

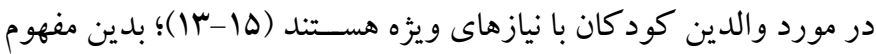

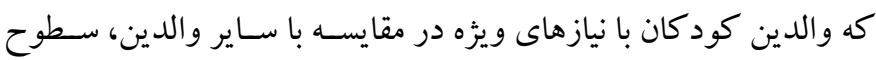

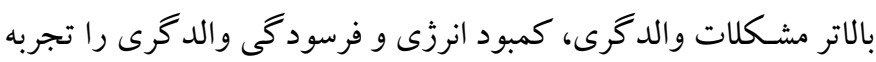

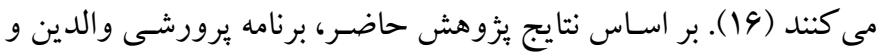

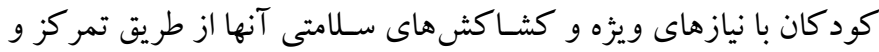
تأكيد بر ابعاد شــاختى، اجتماعى و هيجانى در هر دو والدين و كود كان

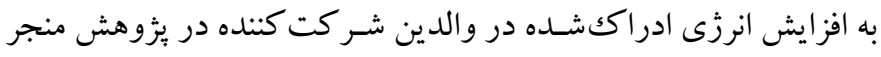

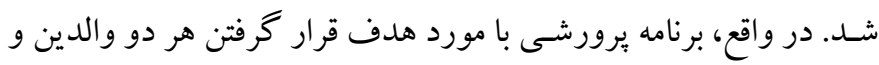

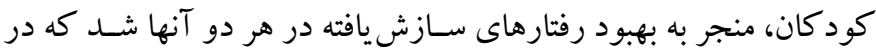
نتيجه آن، مشـكلات والد-فرزند كمتر و انرزى ادراككشـــه والدگرى

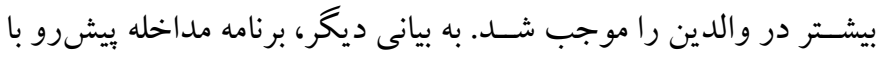

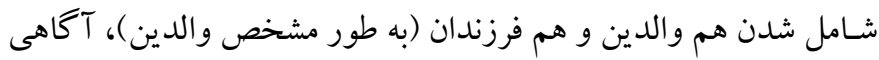

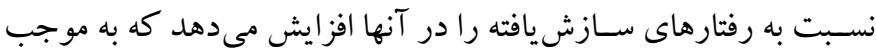
رفتار هاى سازش يافته بيشتر طرفين، والدين انرزى بيشترى براى والدكرى و نخهارى از فرزندانشان ادراكك مى كنند. از سويى ديخر، ذهن آكاهى مسئله بسيار برجسته ديخرى است كه در

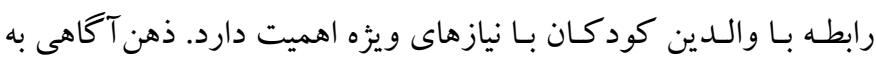

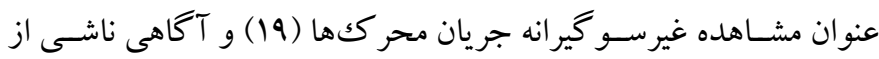

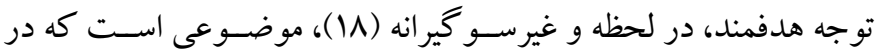
خانو ادههاى كود كان با نيازهاى ويزٔه مى تو اند ســوح بـايين ترى داشـته

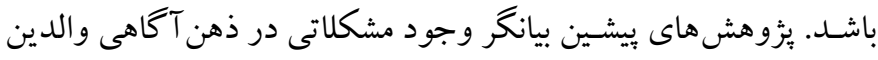

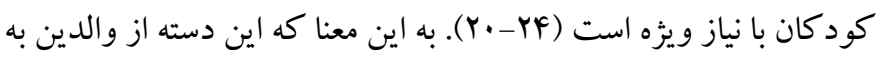
طور عمده از ذهن آكاهى كمترى برخوردار هستـند كه اين سطوح كمتر

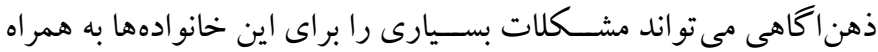

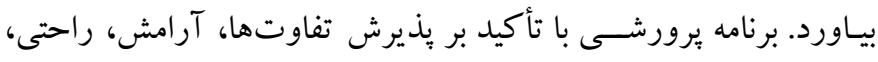

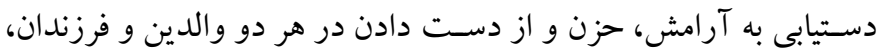


نقش هر يكك از نويسـند كان: در يزوهش حاضر نويسنده نخست و دوم در جلسات

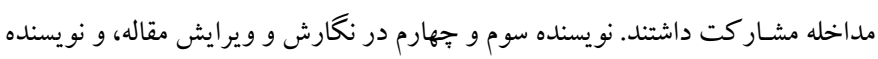
ينجم نيز در جمع آورى و تحليل دادهها، نقش داشتند.

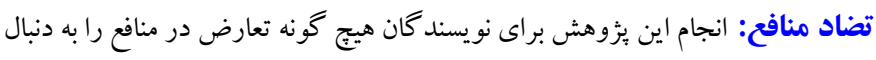

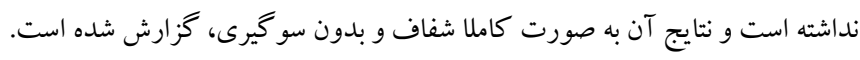
تشكر و قدردانى: بدين وسيله از مسئولان مدارس استثنايى ناحيه يك رشت، والدين

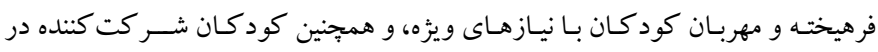
يثزوهش، صميمانه سياس كز اريم.
ملاحظات اخلاقى

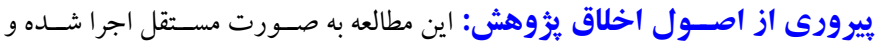
حاصل ياياننامه و طرح ئوهشى مصوب نيست. همجنين يزوهش حاضر با مجوز اداره

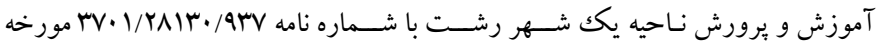

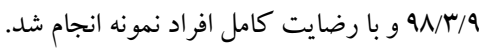
حامى مالى: يُزوهش حاضـر بدون هيج گُونه حمايت مالى از سـوى سـازمان خاصسى انجام شده است. 


\section{References}

1. Maciver D, Rutherford M, Arakelyan S, Kramer JM, Richmond J, Todorova L, et al. Participation of children with disabilities in school: A realist systematic review of psychosocial and environmental factors. PLOS ONE. 2019; 14(1): e0210511. DOI: 10.1371/journal.pone.0210511 [Link]

2. Sullivan AL, Farnsworth EM, Susman-Stillman A. Patterns and predictors of childcare subsidies for children with and without special need. Children and Youth Service Review. 2018; 88: 218-228. [Link]

3. Gernsbacher MA, Raimond AR, Balinghasay MT, Boston JS. "Special needs" is an ineffective euphemism. Cogn Res Princ Implic. 2016; 1: 29. DOI: 10.1016/j.childyouth.2018.03.002 [Link]

4. Bagheri Sheykhangafshe F, Shabahang R, Abolghasemi A. Prediction of the Food Neophobia by Dimensions of Personality and Parenting Styles. J Child Ment Health. 2018; 5(2): 25-35. [Persian]. [Link]

5. Serbin LA, Hubert M, Hastings PD, Stack DM, Schwartzman AE. The influence of parenting on early childhood health and health care utilization. J Pediatr Psychol. 2014; 39(10): 1161-1174. DOI: 10.1093/ jpepsy/jsu050 [Link]

6. He J, Shi J, Luo B. Parenting and children's cognitive development. Gifted Education International. 2006; 22(1): 86-100. DOI: 10.1177/026142940602200112 [Link]

7. Mensah MK, Kuranchie A. Influence of parenting styles on the social development of children. Academic Journal of Interdisciplinary Studies. 2013; 2(3): 123-129. DOI: 10.5901/ajis. 2013. V2n3p123 [Link]

8. Danzig AP, Dyson MW, Olino TM, Laptook RS, Klein DN. positive parenting interacts with child temperament and negative parenting to predict children's socially appropriate behavior. J Soc Clin Psychol. 2015; 34(5): 411-435. DOI: 10.1521/jscp. 2015.34.5.411 [Link]

9. Ong MY, Eilander J, Saw SM, Xie Y, Meaney MJ, Broekman BFP. The influence of perceived parenting styles on socio-emotional development from prepuberty into puberty. Eur Child Adolesc Psychiatry. 2018; 27(1): 37-46. DOI: 10.1007/s00787-017-10169 [Link]

10. Janisse HC, Barnett D, Nies MA. Perceived energy for parenting: a new conceptualization and scale. J Child Fam Stud. 2009; 18: 312-322. DOI: 10.1007/ s10826-008-9232-z [Link]
11. Hubert S, Aujoulat I. Parental burnout: when exhausted mothers open up. Front Psychol. 2018; 9: 1021. DOI: 10.3389/fpsyg.2018.01021 [Link]

12. Algood CL, Harris C, Hong JS. Parenting success and challenges for families of children with disabilities: an ecological systems analysis. J Hum Behav Soc Environ. 2013; 23(2): 126-136. DOI: 10.1080/ 1091 1359.2012.747408 [Link]

13. Ha J-H, Greenberg JS, Seltzer MM. Parenting a child with a disability: the role of social support for African American parents. Fam Soc. 2011; 92(4): 405-411. DOI:10.1606/1044-3894.4150 [Link]

14. O'Connell T, O'Halloran M, Doody O. Raising a child with disability and dealing with life events: a mother's journey. J Intellect Disabil. 2013; 17(4): 376 -386. DOI: 10.1177/1744629513509794. [Link]

15. Crown NJ. Parenting a child with disabilities: personal reflections. J Infant Child Adolesc Psychother. 2009; 8(1): 70-82. DOI: 10.1080/152891 60802683492 [Link]

16. Gérain P, Zech E. Does informal caregiving lead to parental burnout? Comparing parents having (or not) children with mental and physical issues. Front Psychol. 2018; 9: 884. DOI: 10.3389/fpsyg. 2018.00884 [Link]

17. Davis DM, Hayes JA. What are the benefits of mindfulness? A practice review of psychotherapyrelated research. Psychotherapy. 2011; 48(2): 198208. DOI: $10.1037 / \mathrm{a} 0022062$ [Link]

18. Ruiz-Fernández MD, Ortíz-Amo R, Ortega-Galán ÁM, Ibáñez-Masero $\mathrm{O}$, Rodríguez-Salvador $\mathrm{MD}$, Ramos-Pichardo JD. Mindfulness therapies on health professionals. International journal of mental health nursing. 2020; 29(2):127-40. DOI: 10.1111/inm. 12652 [Link]

19. Norton KR, Griffith GM. The impact of delivering mindfulness-based programs in schools: A qualitative study. Journal of Child and Family Studies. 2020; 29(9):2623-36. DOI: 10.1007/s10826-020-01717-1 [Link]

20. Petcharat M, Liehr P. Mindfulness training for parents of children with special needs: Guidance for nurses in mental health practice. J Child Adolesc Psychiatr Nurs. 2017; 30(1): 35-46. DOI: 10.1111/jcap.12169 [Link]

21. Whittingham K. Parents of children with disabilities, mindfulness and acceptance: a review and a call for research. Mindfulness. 2014; 5(6): 704-709. DOI: 10.1007/s12671-013-0224-8 [Link]

22. Chan TO, Lam S-F. Mediator or moderator? The role of mindfulness in the association between child 
behavior problems and parental stress. Res Dev Disabil. 2017; 70: 1-10. DOI: 10.1016/j.ridd.2017. 08.007 [Link]

23. McDonald EE, Hasting RP. Mindful parenting and care involvement of fathers of children with intellectual disabilities. J Child Fam Stud. 2010; 19(2): 236-240. DOI: 10.1007/s10826-008-9243-9 [Link]

24. Rayan A, Ahmad M. Mindfulness and parenting distress among parents of children with disabilities: A literature review. Perspect Psychiatr Care. 2018; 54(2): 324-330. DOI: 10.1111/ppc.12217 [Link]

25. Shabahang R, Khosrojavid M, Ahmadi A. The role of attitude and resiliency in predicting the quality of life of parents of children with special needs. J Child Ment Health. 2018; 5(3): 11-21. [Persian]. [Link]

26. Lecavalier L, Leone S, Wiltz J. The impact of behaviour problems on caregiver stress in young people with autism spectrum disorders. J Intellect Disabil Res. 2006; 50(3): 172-183. DOI: 10.1111/ j.1365-2788.2005. 00732.x [Link]

27. Ha J-H, Hong J, Seltzer MM, Greenberg JS. Age and gender differences in the well-being of midlife and aging parents with children with mental health or developmental problems: report of a national study. $\mathbf{J}$ Health Soc Behav. 2008; 49(3): 301-316. DOI: 10.1177/002214650804900305 [Link]

28. Seltzer MM, Greenberg JS, Floyd FJ, Hong J. Accommodative coping and well-being of midlife parents of children with mental health problems or developmental disabilities. Am J Orthopsychiatry. 2004; 74(2): 187-195. DOI: 10.1037/0002-9432.74. 2.187 [Link]

29. Singer GHS. Meta-analysis of comparative studies of depression in mothers of children with and without developmental disabilities. Am J Ment Retard. 2006; 111(3): 155-169. DOI: 10.1352/0895-8017 [Link]
30. Cohen HJ. Child care for children with special needs. Pediatrics, 1994; 94(6): 1055-1059. [Link]

31. Burton RS, Zwahr-Castro J, Magrane CL, Hernandez $\mathrm{H}$, Farley LG, Amodei N. The nurturing program: an intervention for parents of children with special needs. J Child Fam Stud. 2018; 27(4): 1137-1149. DOI: 10.1007/s10826-017-0966-3 [Link]

32. Hirsjärvi S, Perälä-Littunen S. Parental beliefs and their role in child-rearing. European Journal of Psychology of Education. 2001; 16(1): 87-116. DOI: 10.1007/BF03172996 [Link]

33. Bornstein MH, Hahn C-S, Haynes OM. Maternal personality, parenting cognitions and parenting practices. Dev Psychol. 2011; 47(3): 658-675. DOI: 10.1037/a0023181 [Link]

34. Bailie C, Kuyken W, Sonnenberg S. The experiences of parents in mindfulness-based cognitive therapy. Clin Child Psychol Psychiatry. 2012; 17(1): 103-119. DOI: $10.1177 / 1359104510392296$ [Link]

35. Brems C, Sohl MA. The role of empathy in parenting strategy choices. Family Relations: An Interdisci plinary Journal of Applied Family Studies. 1995; 44(2): 189-194. DOI: $10.2307 / 584808$ [Link]

36. Ridderinkhof A, De Bruin EI, Brummelman E, Bögels SM. Does mindfulness meditation increase empathy? An experiment. Self-Identity. 2017; 16(3): 251-269. DOI: 10.1080/15298868.2016.1269667 [Link]

37. Walach H, Buchheld N, Buttenmüller V, Kleinknecht N, Schmidt S. Measuring mindfulness - the Freiburg Mindfulness Inventory (FMI). Pers Individ Dif. 2006; 40(8): 1543-1555. DOI: 10.1016/j.paid.2005.11.025 [Link]

38. Ghasemi Jobaneh R, Arab Zadeh M, Jalili Nikoo S, Mohammad Alipoor Z, Mohsenzadeh F. Survey the validity and reliability of the Persian version of short form of Freiburg mindfulness inventory. JRUMS. 2015; 14(2): 137-150. [Persian]. [Link] 